\title{
TRADITIONAL BIRTH ATTENDANTS IN BOPHUTHATSWANA (BO-MMAABOTSETSE)
}

\author{
Caroline Ntoane
}

\section{INTRODUCTION}

The predominant role of women in health care activities is true for most countries, developing and developed, and is a phenomenon which predates the emergence of modern health care systems. Women are expected to be health educators, to teach sound health practices, to limit family size and to take children to the formal health care services when necessary. 1

Women also serve without monetary compensation as Traditional Birth Attendants (TBA), who still deliver most of the babies, in the developing world. Appropriate care during pregnancy and childbirth is crucial to women's health and well-being, as well as to that of future generations. The World Health Organisation (WHO) emphasises the particular importance of adequate coverage of women during pregnancy and childbirth. At its conference ${ }^{2}$ on appropriate technology for birth WHO made some recommendations which it believes are relevant to perinatal services worldwide, which were, among others, that health ministries should establish specific policies regarding appropriate birth technology for the private and nationwide services. It also encouraged the training of birth attendants who should promote communication between members of the health team and the pregnant woman and her family.

The selection and training of the TBA's vary from country to country based on criteria which may be established by health professionals and members of the community. ${ }^{3}$

In 1983 care groups were incepted in Bophuthatswana under the Community Development policy. ${ }^{4}$ These women called "balekodi" function as health educators and mainly do follow-up of psychiatric. tuberculosis and malnourished children. Apart from their follow-up function care groups collect some base-line data in their own villages. This base-line data is used by community health care personnel in the provision of health services.

Emanating from the care groups is a cadre of community workers known as maternity helpers (bo-Mmaabotsetse). Mmaabotsetse is usually a woman, preferably married with some experience in delivering babies. The family of a pregnant woman chooses Mmaabotsetse who accompanies the pregnant woman to the ante-natal clinic and joins the health education lectures pertaining to ante-natal and post-natal care. Although

\section{Summary}

A survey was conducted among the 104 traditional birth attendants (bommaabotsetse) in Bophuthatswana during the 1985 winter vacation. The objective of the survey was to estimate the number of women practising as well as provide their characteristics and practices. Findings revealed that bommaabotsetse were elderly women with an average age of 58 years, were married and had a considerable period of experience. Preference for delivery in a health service, which is not always accessible, is discussed with a suggestion of a few options. It is concluded that some women in rural Bophuthatswana make a conscious choice of home delivery even when modern delivery facilities are available. A training programme for bommaabotsetse with adequate support and supervision is recommended.

\section{Samevatting}

'n Opname is gedurende die 1985 wintervakansie gedoen onder die 104 tradisionele vroedvroue (bo-

mmaabotsetse) in Bophuthatswana. Die doel van die opname was om te bepaal hoeveel vroue praktiseer en om hulle eienskappe en praktyke vas te stel. Die bevindings het aangetoon dat bommaabotsetse ouer vroue met 'n gemiddelde ouderdom van 58 jaar. getroud en met 'n aansienlike tydperk van ondervinding was. Voorkeur vir bevallings in 'n gesondheidsdiens, wat nie altyd toeganklik was nie, word bespreek en 'n paar moontlikhede voorgestel. Die gevolgtrekking word gemaak dat sommige vroue in landelike Bophuthatswana bewustelik besluit op in bevalling tuis selfs wanneer moderne verlossingsfasiliteite beskikbaar is. 'n Opleidingsprogram vir bo-

mmaabotsetse met voldoende ondersteuning en toesig word aanbeveel.

Mmaabotsetse looks after the woman before and after delivery, she is not to interfere with the domestic affairs of her clients.

At the time of the survey the syllabus employed in the training of bo-

Mmaabotsetse did not include assistance with birth. ${ }^{5}$ This implies that bo-
Mmaabotsetse should not interfere with the delivery process even under emergency situations. During an emergency delivery, Mmaabotsetse observes and leaves nature to take its course.

Because of limited resources only one community health nurse was available for training bo-Mmaabotsetse at the time of the survey, and for the same reason, no field supervision had been implemented. A few of bo-Mmaabotsetse had more tha three lectures, and even these had neve. been evaluated to check their performance. Supervision, apart from its critical role in supporting high quality services and coverage of the target population, provides the final basis for modifying and refining the training course itself. There are obviously logistical and practical obstacles to carrying out a rigorous evaluation of the performance of isolated rural health workers. As a starting point in our situation we decided to launch a community based survey in order to obtain some background information about Mmaabotsetse in Bophuthatswana. The survey was therefore designed with the following objectives in mind:

To obtain an estimate of women practising as bo-Mmaabotsetse To provide some demographic characteristics of bo-Mmaabotsetse

To provide information on the knowledge, attitudes and practices bo-Mmaabotsetse.

\section{METHOD}

During the July vacation in 1985, the University of Bophuthatswana nursing students went to their respective home villages of Bophuthatswana and through the community health nurses identified boMmaabotsetse active in the local communities.

A structured questionnaire was used to obtain information on the personal characteristics, knowledge, practices and attitudes of bo-Mmaabotsetse. A total of 104 bo-Mmaabotsetse were identified and data were analysed for the ninety-four (94) women who provided information on their training. These women were divided into three categories for the purpose of analysis. The first category consisted of women who claimed to have received some training from health personnel as

Mmaabotsetse. This group will be referred to as: trained by health personnel.

The second category consisted of women who reported to have been trained by relatives. This group is referred to as: trained by relatives. 
The third category consisted of women who did not receive any form of training, and they will be referred to as: no training.

\section{FINDINGS}

\section{Training}

Of the ninety-four women who had information on their training, forty were trained by health personnel, twenty-four by relatives and thirty had received no form of training.

\section{Personal characteristics and experience of Mmaabotsetse}

The tendency of this sample indicated that the majority of bo-Mmaabotsetse are elderly women over 55 , with the mean age of 58 years. Out of the 94 bo-

Mmaabotsetse 92 (98\%) were either married, divorced or widowed. Only 2 (2\%) of the women were single. This is consistent with the Motswana tradition th the traditional midwife has to be an e. ly woman, who has once delivered a woman and has got children of her own, implying that she has to be married.

Generally most programmes require that auxilliaries be literate so that they can read the training manuals, keep simple activity report and understand written directions while others, due to lack of literate persons available, select and train workers who cannot read and write. It is often felt that if too highly educated, the auxilliary will feel superior to the people in the community and worse still cease being an auxilliary when a better paying or higher job becomes available.

In this survey $43(46 \%)$ of boMmaabotsetse had higher primary education, 25 (27\%) had lower primary education and $21(22 \%)$ had no schooling. A small proportion of bo-Mmaabotsetse 4 (5\%) had high school education with one Social Worker.

irty-one $(33 \%)$ of the women, had p. ised as Mmaabotsetse for less than I year and $32(34 \%)$ had practised for $1-5$ years. While $12(13 \%)$ had $6-10$ years of experience, the remaining $17(18 \%)$ had 11 or more years of practice. Two women could not remember their years of experience.

\section{Knowledge practice and attitudes of Mmasbotsetse}

Responses on the knowledge, and practices of bo-Mmaabotsetse were categorised according to their training.

When questioned about the advice they would give to the woman during pregnancy, the following responses (in rank order) flowed from bo-Mmaabotsetse trained by health personnel:

1. Proper nutrition

2. Avoid sleep during day time

3. Exercises

Those trained by relatives responded as follows:

1. Proper nutrition

2. Avoid sleep during day time

3. Avoid eggs

Untrained bo-Mmaabotsetse's responses were similar to those trained by relatives.

The majority of bo-Mmaabotsetse from all the categories mentioned the following signs of a woman falling into labour: (listed in rank order)

1. Labour pains

2. Draining of liquor

3. Show

4. Woman makes faces

Asked about the danger signals that should be observed during pregnancy, the following responses were given by the three categories:

1. Vaginal bleeding

2. Severe vomiting

3. Rupture of membranes

4. Severe headache and dizziness.

Asked about the advice they would give to a woman post-natally, the majority from all categories said they would give advice on the following:

1. Breast feeding

2. How to position the baby and bring wind up

3. Proper nutrition

4. Stay in the bedroom until cord falls off Asked about the reasons why women deliver at home, the following responses were given frequently by bo-Mmaabotsetse from all categories:

Transport problems: It was indicated by bo-Mmaabotsetse that although women may choose to deliver in the health centre, lack of transport, or rather the cost of the available transport makes the health services physically and economically inaccessible to them

Attitudes of nurses towards clients: Childbirth is regarded by a traditional Motswana woman as a natural event which must take place in a relaxed atmosphere, where the emotional, psychological and social aspects of the woman should be respected. Such respect according to the women lacks from a hospital or clinic midwife who is just interested in "seeing the baby come out". One actually said: "Most women in the village are afraid of nurses because they are too harsh to women in labour".

Precipitate labour: It was mentioned that more often than not precipitate labour which cannot be predicted lends a woman a home delivery.

Lack of privacy: In support of this reason it was said: "Adults feel that they are being delivered by young nurses who are fit to be their children".

Lithotomy versus squatting: WHO discourages that the pregnant woman be placed in a dorsal lithotomy position during labour and delivery, but rather encourages walking during labour and that each woman must freely decide which position to adopt during delivery. BoMmaabotsetse expressed that some women feel threatened by the position adopted in a health centre during delivery, as they feel more comfortable in a squatting position.

Lack of health services nearby: It has been declared by WHO that Primary Health Care is available to the whole population if among others, it is within the radius of $5 \mathrm{~km}$ or within one hour's walk or travel. Bo-Mmaabotsetse expressed that women had a problem of long distance travelling to the nearest health centres.

Lack of money to book at the health centre: Although the fee paid for maternity services in a rural clinic may be regarded as nominal by health administrators, for an unemployed woman who has other basic needs to take care of, it becomes difficult to identify health as a priority.

See Tables 1 and 2 for taboos and protection of mother and baby respectively.

\section{DISCUSSION}

Epidemiology has thus far interested itself in studying the distribution and determinants of disease with a description of simple characteristics of the host such as age, sex and geographical location. The characteristics of the host such as behaviour, beliefs and practices of the host are often overlooked. These "soft" data are undoubtedly important in the study of disease distribution and determinants of ill health. ${ }^{6}$ The proponents of PHC view local community participation as a necessary
TABLE 2. PROTECTION OF MOTHER AND YABY DURING PUEPERIUM

1. Ditantanyane (herb) given to the baby to protect it from infection.

2. Avoid eating morogo (traditional spinach) otherwise baby will develop diarrhoes.

. Application of cow-dung or wood ash to hasten healing process of the cond.

. Avoid sexual intercourse until baby is nix montha old, otherwise the breast milk will be affected.

. Stay home for 3 months, do not visit neighbours to avoid methala (tracks).

6. Previous use of contraxeptives - baby will have sores all over the body.

7. Menstruating woman getting into Motsetse's bedroom must use a herb callod "mokatelo". Ground mokatelo is mixed with cow-duns plus the woman's menstrual blood. This is applied as a cross on the woman t beck and on the beby' cord. This will protect mother from losing appetice and baby from developing a hernis.

8. Drink kgaba (herb) to avoid misfortune e.s. in canes of illepitimecy parents may be croas with their daughter and baby may be a still-birth. 
precondition for a successful implementation of the PHC strategy. In addition to this, studying, understanding and respecting the conceptions and traditional beliefs of the local community will enable health workers to address it with relevant messages on health promotion and disease prevention. The medical school is Sokoto State of Nigeria ${ }^{7}$ has made the first attempt in Africa to examine traditional medicine as a distinct academic discipline in the medical curriculum. For example, in obstetrics and gynaecology there would be discussion of traditional childbirth techniques, beliefs and practices. The purpose of the course is not to produce traditional medical practitioners but rather to educate medical students in some broad general concepts, principles, practices and methods, so as to grasp the alternative strategies and philosophies of traditional medicine and knowledge of how it may be evaluated, used and developed for the benefit of the communities within which they will be working. Werner and Bower ${ }^{8}$ and

McClaim' holds the same views about traditional practice: that their beneficial effects should be encouraged, the neutral tolerated, the uncertain allowed until medical research determines their safety, and the harmful discouraged.

While a few of the practices such as applying cow dung to the umbilical cord stump are potentially harmful, some forbidden foods, postures and social contacts can be seen as positive preventive measures. ${ }^{10}$ Avoidance of protein-rich foods may place a pregnant woman and foetus at risk nutritionally. However, depending on the source, preservation and storage of meat and eggs, such food taboos could serve as protection of the pregnant woman from certain food-borne diseases.

The traditional squatting position of childbirth is usually easier for the mother, because it is said that the weight of the baby helps her to push. The lithotomy position is easier for the midwife, but not for the mother.

As Read" suggests "the underlying reason for the period of seclusion is often the fear of pollution from the woman who has given birth". If the woman is not protected during this period, especially from too many social contacts she may easily get infected.

When interviewed about the advantages they saw in delivering in a health centre, bo-Mmaabotsetse showed positive attitudes towards modern health care giving among others, reasons such as "midwives are more experienced and their training allows them to deal with labour complications".

Although the above statement would indicate preference for delivery in a health service, lack of transport, or rather the cost of the available transport and lack of money to book at the health centre make them choose to deliver at home. It would be argued therefore that place of delivery in the rural Bophuthatswana is determined by the available resources not by the adherence to traditional practices per se. However, the attitudes of health workers may discourage even those who were able to come.

The foregoing arguments suggest a few options viz; in view of the socio-economic status of the rural communities extension of the accessible maternity services are urgently needed. The limited number of professional midwives who serve in the rural areas make it impossible for them to provide multiple services for too many people. The situation gets worse during a mobile clinic where one professional nurse is expected to provide multiple services for too many people. With only one team member qualified to do examinations, prescribe medication and supervise the medical service, the quality of medical care is adversely affected, particularly when one is observing pregnant women for the first time. The second option would be to train bo-Mmaabotsetse in a more realistic way with clear methods and techniques that have to be employed. These methods have to be acceptable both to those who use them and to those on whom they are used. Conditions for their selection and by whom they will be selected should be clear. Whether they are to be renumerated or not should also be clearly spelled out. Prospects for advancing in their career should be stated if any and also how this will be controlled and organised. The question of volunteers should also be sorted out. Lastly but not least in importance is to consider the use of health indicators. "Indicators" as the name suggests are an indication of a given situation, or a reflection of that situation. ${ }^{12}$ Among the list of 12 global indicators which were adopted by the Thirty-fourth World Health Assembly in 1981 the following could be used in our case:

- At least $5 \%$ of the gross national product should be spent on health.

- Resources are equally distributed, in that per capita expenditure as well as the staff and facilities devoted to primary health care are similar for various population groups or geographical areas, such as urban and rural areas.

- Trained personnel should be available for attending pregnancy and childbirth, and caring for children up to at least 1 year of age.

\section{CONCLUSION}

Findings on the knowledge, practices and attitudes of bo-Mmaabotsetse showed clearly that delivery care is not commonly part of their function. They are generally well informed about the antenatal and postnatal care. Some women in the rural Bophuthatswana seem to make a conscious choice of a home delivery even when modern facilities for maternity care are readily available as shown by the above findings. As part of this choice they would utilise the services of a traditional midwife.

The survey has provided information on the existence and present function of boMmaabotsetse. It has however, raised more questions than it has answered. Among the most important questions are: Why do some women in rural
Bophuthatswana abstain from maternity care inspite of its availability and accessibility?

Which most important qualities not found in the modern maternity service does the traditional midwife offer to the pregnant and delivering woman in the rural village?

Should we as health workers train the identified traditional midwives in order to make home deliveries optimally safe for the mothers who might prefer this alternative?

Or, in view of the fact that hygienic conditions in the majority of homes in the rural areas are still far from optimal - should the Department of Health still encourage institutional deliveries and concentrate on making those attractive to all women?

Which specific policy should be formulated by the Department in order to provide optimal care for mothers and children in rural Bophuthatswana in the future?

The possible approach to the abov questions would be to try to adopt the culturally relevant and quantitatively valuable elements of traditional maternity care to the technically satisfactory care delivered by the modern maternity service. In other words, we as health workers from the modern health sector should view the whole issue as reciprocal, that is, that we should, while teaching the traditional midwives, also learn from them. The benefits accrued from the use of the traditional midwives in other countries should be used as a lesson for other developing countries with similar problems. This should, however, be done with caution because problems present themselves differently under different conditions.

\section{RECOMMENDATIONS}

It is recommended that the training programme be made part of the nati health policy which aims at reducing maternal and child morbidity and mortality. Also that an evaluation programme be initiated to measure the impact of these workers.

It is also recommended that the Department of Health and Social Welfare sets its goals for percentages of both home and health facility births according to available resources.

More research into the traditional beliefs and practices should be done.if health workers want to shape materhity care towards the community's life style and expectations for maximum coverage.

\section{REFERENCES}

1. Women, Health and Development. World Health Organization, Offset Publication No. 90. Geneva. 1985.

2. Appropriate Technology for Birth. The Lancet, August 24, 1985.

3. Alternative approaches to Meeting Basic Health Needs in Developing Countries. A joint UNICEF/WHO Study. Geneva, 1975.

4. Community Development Activities/Programmes. Department of 
Health and Social Welfare. 1983

Bophuthatswana.

5. Community Development in Health.

Bophelong Hospital, Health Ward, Molopo.

Preliminary Manual for Trainers of

Voluntary Care Groups.

6. Staugard F. The Epidemiology of Beliefs and Practices. The Epidemiology Unit. Gaborone.

7. Traditional Medicine and Modern Medical Curriculum. The Lancet, July 26, 1986.

8. Werner and Bower. Helping Healsh Workers Learn. US. A. The Hesperian Foundation.

9. McClain C. Comparative Framework for the Study of Childbirth. In Clark L. Traditional Beliefs and Practices of Pregnancy and Childbirth. Gaborone.

10. Clark L. Traditional Beliefs and Pracrices of Pregnancy and Childbirlh. Gaborone Town Council Clinics. Gaborone.
11. Read M. Cullure, Healih and Disease. In Community, Culture and Care. Saint Louis. The C.V. Mosby Co. 1981.

12. Development of Indicators for Monitoring Progress. Towards Health for All by the Year 2000. WHO. Geneva. 1981

\section{ACKNOWLEDGEMENTS}

1. The author is indebted to Mrs lekgetha, the Deputy Director of Nursing in Bophuthatswana and founder member of the Care-Groups for allowing me access to bo-Mmauhotserse.

2. My warmest thanks to Ms Moipolai and Mrs Mosaka the trainers of Care-groups for the contribution they made to this study.

3. I would also like to acknowledge the help and support of members of the School of Health and Social Sciences at Unibo.

4. I am also thankful to the Unibo nursing students who interviewed bo-Mmaabotsetse during their vacation.

5. Last but not least. I would like to say "thank you" to Mrs Ratnam, our Secretary, for typing this paper, and to Meryl Hammond of the Consultancy for Alternative Educarion for her feedback and encouragement to puhlish this paper.

C.M. Ntoane R.N., R.M., Dip in Intensive Care Nursing. B.A. (Cur.) Hons., B. A. (Cur.) Department of Nursing Science University of Bophuthatswana 